\title{
Recruitment of IFT proteins during flagellum construction in Trypanosoma brucei
}

\author{
E Bertiaux*, P Bastin, B Rotureau \\ From Cilia 2014 - Second International Conference \\ Paris, France. 18-21 November 2014
}

\section{Introduction}

Trypanosoma brucei is a protozoan parasite responsible for sleeping sickness in Central Africa. It is transmitted by the bite of the tsetse fly. During its complex life cycle, it undergoes significant morphological changes including extensive variations in flagellum length ( 3 to $30 \mu \mathrm{m})$. The flagellum is an essential organelle for parasite survival as it is involved in morphogenesis, movement, division and adhesion of the trypanosome. Intraflagellar transport (IFT) refers to the movement of protein complexes between the membrane and the microtubules. Like in other eukaryotes, IFT is essential for the construction of the trypanosome flagellum. Studies in the green alga Chlamydomonas suggested that the total amount of IFT proteins injected in the flagellum defines its final length: the higher the amount, the longer the flagellum. Moreover, the total amount of IFT proteins would be injected at once.

\section{Methods}

We have studied the distribution of IFT proteins during the development of Trypanosoma brucei. Expression and localization of IFT proteins was analyzed by immunofluorescence with antibodies against two IFT proteins (IFT22 and IFT172).

\section{Results}

The analysis of fluorescence intensities revealed that the total amount of IFT proteins in the flagellum is directly proportional to its length in all stages examined, as observed in Chlamydomonas. However, the IFT protein concentration per unit of flagellum length is constant at any steps of flagellum formation. These results were confirmed by monitoring protein trafficking in live cells expressing the TdTomato::IFT81 fusion protein.

Trypanosome Cell Biology Unit, INSTITUT PASTEUR, Paris, France

\section{Conclusions}

Our results lead to a new model where IFT proteins would be progressively recruited to the flagellar compartment during elongation of the organelle. This raises the question of the regulation of IFT injection to the flagellum that will be addressed by studying the formation of very long or very short flagella in several development stages in the tsetse fly.

Published: 13 July 2015

doi:10.1186/2046-2530-4-S1-P47

Cite this article as: Bertiaux et al:: Recruitment of IFT proteins during

flagellum construction in Trypanosoma brucei. Cilia 2015 4(Suppl 1):P47.
Submit your next manuscript to BioMed Central and take full advantage of:

- Convenient online submission

- Thorough peer review

- No space constraints or color figure charges

- Immediate publication on acceptance

- Inclusion in PubMed, CAS, Scopus and Google Scholar

- Research which is freely available for redistribution
() Biomed Central 